\title{
Pedagogical management of resolving conflict situations in educational institution
}

\section{Gestão pedagógica de resolução de situações de conflito em instituições de ensino}

\section{Gestión pedagógica de la resolución de situaciones de conflicto en la institución educativa}

\author{
Marina Georgiyevna Sergeeva ${ }^{1}$ iD , Dmitry Vladimirovich Lukashenko ${ }^{1}$ iD \\ Maria Lvovna Kunitsyna ${ }^{2}$ iD , Konstantin Zaurovich Abdula-Zade ${ }^{3}$ iD
}

\footnotetext{
${ }^{1}$ Research Institute of the Federal Penitentiary Service of Russia, Moscow, Russia.

2 Peoples' Friendship University of Russia (RUDN University), Moscow, Russia.

${ }^{3}$ Center for Sports Training of National Teams of Russia, Moscow, Russia.
}

\section{Corresponding author:}

Marina Georgiyevna Sergeeva

Email: sergeeva198262@mail.ru

How to cite: Sergeeva, M. G., Lukashenko, D. V., Kunitsyna, M. L., \& Abdula-Zade, K. Z. (2021). Pedagogical Management of Resolving Conflict Situations in Educational Institution. Revista Tempos e Espaços em Educação, 14(33), e16558. http://dx.doi.org/10.20952/revtee.v14i33.16558

\begin{abstract}
The pedagogical process in an educational institution is determined by the interaction of individuals. Therefore, the decisive factor in the professional development of a teacher is the ability to act as a subject of pedagogical activity and build dialogical interaction with other subjects. Dialogical interpersonal interaction is a prerequisite for the efficient pedagogical activity in an educational institution. In the process of mastering dialogical skills, the professional development of a teacher is ensured. A significant part of the teacher's professional competencies is associated with interpersonal communications, which focus our attention on the role of dialogical interaction in the professional development of a teacher. Pedagogical competencies are aimed at the implementation of professional activities and the ability to build competent dialogical interaction in the educational process. The optimal result of dialogical interactions is the mastering by the teacher of a certain set of knowledge, professional skills, and personal characteristics, which, in our opinion, could be considered as the criteria of professional growth. We believe that optimization of dialogical interaction between participants in educational relations requires special attention. In the educational institution, it is necessary to pay more attention to the implementation of the communicative potential of the individual, creating a comfortable educational environment for twoway communication. The communicative mobility of all subjects of interaction should be developed
\end{abstract}


at pedagogical councils, training sessions, and parent-teacher meetings with the participation of a school psychologist.

Keywords: Conflict. Teaching staff. Dialogical interaction.

\section{RESUMO}

O processo pedagógico em uma instituição de ensino é determinado pela interação dos indivíduos. Portanto, o fator decisivo no desenvolvimento profissional de um professor é a capacidade de atuar como sujeito da atividade pedagógica e construir interação dialógica com outras disciplinas. A interação interpessoal dialógica é um pré-requisito para a atividade pedagógica eficiente em uma instituição de ensino. No processo de domínio das habilidades dialógicas, o desenvolvimento profissional do professor é garantido. Parte significativa das competências profissionais do professor está associada à comunicação interpessoal, que focaliza nossa atenção no papel da interação dialógica no desenvolvimento profissional de um professor. As competências pedagógicas visam a implementação de atividades profissionais e a capacidade de construir uma interação dialógica competente no processo educacional. O resultado ótimo das interações dialógicas é o domínio pelo professor de um determinado conjunto de conhecimentos, habilidades profissionais e características pessoais, que, em nossa opinião, podem ser considerados como critérios de crescimento profissional. Acreditamos que a otimização da interação dialógica entre os participantes nas relações educacionais requer atenção especial. Na instituição de ensino, é necessário dar mais atenção à implementação do potencial comunicativo do indivíduo, criando um ambiente educacional confortável para a comunicação bidirecional. A mobilidade comunicativa de todos os sujeitos de interação deve ser desenvolvida em conselhos pedagógicos, sessões de formação e reuniões de pais e professores com a participação de um psicólogo escolar.

Palavras-chave: Conflito. Pessoal docente. Interação dialógica.

\section{RESUMEN}

El proceso pedagógico en una institución educativa está determinado por la interacción de los individuos. Por tanto, el factor decisivo en el desarrollo profesional de un docente es la capacidad de actuar como sujeto de la actividad pedagógica y construir una interacción dialógica con otros sujetos. La interacción dialógica interpersonal es un requisito previo para la actividad pedagógica eficiente en una institución educativa. En el proceso de dominar las habilidades dialógicas, se asegura el desarrollo profesional de un docente. Una parte importante de las competencias profesionales del docente está asociada a las comunicaciones interpersonales, que centran nuestra atención en el papel de la interacción dialógica en el desarrollo profesional de un docente. Las competencias pedagógicas están orientadas a la implementación de actividades profesionales y la capacidad de construir una interacción dialógica competente en el proceso educativo. El resultado óptimo de las interacciones dialógicas es el dominio por parte del docente de un determinado conjunto de conocimientos, habilidades profesionales y características personales que, en nuestra opinión, podrían considerarse como criterios de crecimiento profesional. Creemos que la optimización de la interacción dialógica entre los participantes en las relaciones educativas requiere una atención especial. En la institución educativa, es necesario prestar más atención a la implementación del potencial comunicativo del individuo, creando un ambiente educativo cómodo para la comunicación bidireccional. La movilidad comunicativa de todos los sujetos de interacción debe desarrollarse en consejos pedagógicos, jornadas de formación y reuniones de padres y profesores con la participación de un psicólogo escolar.

Palabras clave: Conflicto. Personal docente. Interacción dialógica. 


\section{INTRODUCTION}

A Russian educator M.I. Gulaeva (2015) studied the essence of the process of managing pedagogical conflicts in an educational institution and identified the features and forms of pedagogical management: forecasting (the idea of a possible conflict); prevention (avoiding the emergence of a conflict); stimulation (stimulation of constructive conflicts that are the driving force behind progressive transformations); regulation (pedagogical influence on a conflict situation in order to mitigate or weaken it); conflict resolution (the final stage, at which the conflict decays).

The research work of S.V. Danilenko (2014) is devoted to the same issues and draws attention to one of the forms of pedagogical management, namely the resolution of a conflict situation. According to the researcher, the technology for resolving conflict situations and the use of their positive role in personal development open up great opportunities for the teacher in the educational process, specially creating and resolving these situations in work with students.

The work of Yu.L. Astakhova (2013) reveals the causes of interpersonal conflicts in the teaching staff of an educational institution. According to the researcher, the main causes of pedagogical conflicts include: high demands on the teacher from the educational system (the professional activity of a teacher requires great intellectual, emotional and mental costs); high requirements for the teacher from the parents (teacher's role in the educational process); low communication culture among teachers, etc.

That is, without knowing the general nature of the relationship between team members, it would be difficult to speak about the effective work to prevent conflicts (Vasbieva et al., 2018).

We should also note the research work of A.M. Magdeev and V.R. Mukhadinov, who, analyzing the problem of conflict resolution in educational institutions, come to some interesting conclusions. In addition to traditional methods of managing pedagogical conflicts (cooperation, compromise, adaptation, evasion, rivalry), innovative technologies could be used. So the researcher proposed a modern method of conflict resolution, tested in an educational institution (Magdeev \& Mukhadinov, 2012). The essence of this approach lies in the organizing a reconciliation service, or a conflictological counseling service, the main task of which is to resolve a pedagogical conflict (more precisely, to eliminate the cause of conflict). The activity of this service should be carried out according to specially developed recovery programs which cover the cases of various complexity.

Many scientists note the importance of the teacher's role in the emergence and resolution of pedagogical conflicts (Rybakova, 2012; Svetlov, 2003; Gorev et al., 2018; Bírová et al., 2018; Dolzhich \& Dmitrichenkova, 2018).

As noted by E.A. Selivanov (2012), effective conflict management in the educational environment can be guaranteed due to the formation of a high level of teacher professionalism, mastery of the art to find mutually-acceptable resolution to the conflict situations without losing one's own dignity.

With a responsible and competent attitude to a conflict situation, according to L. Koser's concept of a positive-functional conflict, a pedagogical conflict could perform not only destructive, but also constructive functions for each of the participants in the conflict interaction (Coser, 2007).

Table 1. Functions of pedagogical conflict.

\begin{tabular}{ll}
\hline Constructive functions & Destructive functions \\
\hline Easing mental stress in the classroom; & Depletion of personal resources; \\
Optimization of interpersonal relationships; & Destruction and deterioration of existing ties; \\
Team building; & Weakening of integral unity; \\
Enhancing the creative activity of the class; & Suppression of initiative; \\
Awareness of one's own importance in the team; & Strengthening of destructive leadership; \\
Search for productive solutions; & Aggression; \\
Making new friends & Formation of "the enemy image". \\
& \\
\end{tabular}


Conflicting is not always an unambiguously negative character trait. It is just a quality that is inherent in some people and absent in others. The predominance of some functions over others depends on the attitudes with which the child comes to school.

Someone comes to learn how to communicate and resolve conflicts, someone knows how to build relationships without conflicts, others have completely different tasks and they have no time for conflicts. All children are different, but at school everyone has the same reference point, it is a healthy and harmonious state of mind of the child, teacher and parent (Uchadze, 2010, p. 56; Sharonova et al., 2018, p. 117).

In an educational institution, participants in conflicts could be students, parents, teachers, administration and service personnel. Russian teachers Sheverev V.A. and Kiseleva E.V. (2018) propose to group them into three systems of relationships. Within these systems, different groups of causes of pedagogical conflicts may arise.

Table 2. Participants in the pedagogical conflict in the educational institution.

\begin{tabular}{|c|c|c|}
\hline Relationship system & Conflicting parties & Causes of the conflict \\
\hline \multirow[t]{4}{*}{ Adult - adult } & teacher-administration & $\begin{array}{l}\text { division of power; } \\
\text { job uncertainty }\end{array}$ \\
\hline & teaching staff - parents & $\begin{array}{l}\text { parental dissatisfaction with the quality of services; } \\
\text { increased parental anxiety; } \\
\text { incompetence of the staff of the educational institution }\end{array}$ \\
\hline & teacher - teacher & $\begin{array}{l}\text { separation of spheres of influence and love of children; } \\
\text { psychological discomfort; } \\
\text { non-compliance of staff responsibilities }\end{array}$ \\
\hline & teacher-administrative staff & $\begin{array}{l}\text { status difference; } \\
\text { disrespect for other people's work; } \\
\text { collision of opposing activities }\end{array}$ \\
\hline \multirow[t]{3}{*}{ Adult - Child } & teacher - student & $\begin{array}{l}\text { conflict of actions; } \\
\text { conflict of interest; } \\
\text { relationship conflict }\end{array}$ \\
\hline & teaching staff - student & $\begin{array}{l}\text { status difference; } \\
\text { disrespect for other people's work; } \\
\text { collision of opposing activities }\end{array}$ \\
\hline & administrative staff - student & $\begin{array}{l}\text { violation by the child of the rules of conduct in the educational } \\
\text { institution; } \\
\text { employee incompetence }\end{array}$ \\
\hline Children - children & $\begin{array}{l}\text { student - student } \\
\text { student - group } \\
\text { group - group }\end{array}$ & $\begin{array}{l}\text { household resources, } \\
\text { jealousy, } \\
\text { clarification of social significance. } \\
\text { Peculiar features of children's group functioning }\end{array}$ \\
\hline
\end{tabular}

Despite the fact that the problem of managing conflict behavior of teachers has been thoroughly investigated, issues related to improving the conflict management technologies have not received sufficient recognition and, accordingly, require a systematic approach for effective didactic and educational solutions to pedagogical and social problems. Analysis of the pedagogical conflict as a phenomenon, its participants and functions allows us to conclude that the pedagogical conflict is an integral part of the educational system, and any subjects could become parties to the conflict (Volkova \& Panchenko, 2018). The level of the destructive influence of the conflict on its participants depends on such character traits as conflicting, which some children have, but others 
do not have, as well as the willingness or unwillingness to resolve the emerging contradictions of each participant in the pedagogical conflict.

\section{RESEARCH METHODS}

The development of conflictological competency of the head of an educational institution would be more effective when the following groups of conditions are created (Blinova et al., 2018): - institutional and managerial conditions, including the regulatory, documentary, material and technical support for the development of conflictological competency; - personnel conditions, implying the support of the development of conflictological competency by appropriate qualified professionals (a psychologist, a conflictologist, a mediator); - technological conditions that make it possible to determine the criteria for assessing the level of conflictological competence; psychological and pedagogical conditions, including developing technologies for conflictological training of participants in educational relations and organizing methodological support for the conflictological training.

The level of the leader's conflictological competency is manifested in the models of behavior used in professional activities related to conflict management in an educational institution. Conventionally, three models could be distinguished, which associated, respectively, with a low, medium and high level of development of conflictological competency (Tekucheva \& Gromova, 2016).

The Observer Behavior Model (a low level of the manager's conflictological competency) is characterized by non-intervention in conflict situations (avoidance). At the same time, nonintervention may be due to the fact that the leader does not recognize the signs of conflict at all, or treats it with disregard. This behavior model is formed under the influence of the lack of necessary knowledge and skills in solving difficult situations, as well as under the influence of personal qualities, such as a high level of personal anxiety, low self-esteem of personal and professional qualities, high conformity, etc.

The Judge Behavior Model (medium level of conflictological competency). The leader recognizes the signs of a conflict situation, can identify the conflicting parties and have a certain impact on them, assessing the motives and actions, based solely on personal position. It is possible that the decisions made by the leader in order to resolve the conflict situation would be correct. However, the required level of satisfaction of the parties to the conflict in this case is not always achieved, negative emotions and feelings remain, or the conflict turns into a latent state.

The Mediator Behavior Model (a high level of conflictological competency) is characterized by the fact that the leader pays attention to conflict situations in a timely manner, makes the necessary efforts to ensure that the conflict resolution is as effective as possible and takes into account the interests and needs of each of the parties. By implementing this model, the leader acts as a third party, allowing the conflicting parties to independently come to certain agreements and find a way out of the crisis situation. The leader-mediator, as a rule, has a sufficient knowledge of the technologies that allow organizing the interaction of the conflicting parties to achieve the maximum degree of satisfaction from the resolution of the conflict.

\section{RESULTS}

Conflict resolution scenarios are summarized in Table 3. 
Table 3. Scenarios for conflict resolution in an educational institution.

\begin{tabular}{|c|c|}
\hline Scenario & Conditions for the application \\
\hline Avoiding conflict & $\begin{array}{l}\text { insignificance of the problem underlying the conflict; } \\
\text { inappropriateness of the conflict; } \\
\text { insufficient information to resolve the conflict; } \\
\text { refusal of one or both parties to resolve the conflict; } \\
\text { conditions of complete uncertainty, impossibility to foresee the options for the } \\
\text { development of events; } \\
\text { unpredictability of the consequences of the conflict }\end{array}$ \\
\hline Concessions (adaptation) & $\begin{array}{l}\text { one or both parties admit that they are wrong; } \\
\text { it is necessary to minimize losses; } \\
\text { clear superiority of one of the parties; } \\
\text { increased value of non-conflict behavior in the institutional environment } \\
\text { - a confluence of economic, social or psychological circumstances that make open } \\
\text { conflict impossible; } \\
\text { - risk of damage to the image and / or business reputation; } \\
\text { - impossibility of direct and direct involvement of one or both parties in the resolution } \\
\text { of the conflict; } \\
\text { - imbalance of resources of the parties in the resolution of the conflict }\end{array}$ \\
\hline Hidden actions & $\begin{array}{l}\text { a confluence of economic, social or psychological circumstances that make open conflict } \\
\text { impossible; } \\
\text { risk of damage to the image and / or business reputation; } \\
\text { impossibility of direct involvement of one or both parties in the resolution of the } \\
\text { conflict; } \\
\text { imbalance of resources of the parties in conflict resolution }\end{array}$ \\
\hline Compromise & $\begin{array}{l}\text { lack of time; } \\
\text { lack of resources; } \\
\text { the goals of the conflict are important enough, but not worth the effort; } \\
\text { conflicting parties with equal forces act in mutually exclusive directions and have } \\
\text { directly opposite goals; } \\
\text { there is a possibility of reaching interim agreements on complex issues }\end{array}$ \\
\hline Cooperation & $\begin{array}{l}\text { the need to develop an integrative solution that suits both parties; } \\
\text { enough time to find an alternative that satisfies the interests of both parties }\end{array}$ \\
\hline Enforcement & $\begin{array}{l}\text { prompt, decisive action is needed, possibly in extreme circumstances; } \\
\text { the situation that is vital for the institution and the stronger sides realize that they are } \\
\text { right; } \\
\text { it is necessary to take action against a participant or social group with a destructive type } \\
\text { of behavior }\end{array}$ \\
\hline
\end{tabular}

Requirements for the subject of conflict management:

Ability to prioritize in a conflict situation, to distinguish the primary from the secondary. This ability is provided by observational skills, an important quality necessary to assess the participants in the conflict and their actions.

Inner calmness. This is the attitude to life, which does not exclude a person's energy and activity, and presupposes emotional maturity. Inner calmness allows a person to react sensitively and adequately to the slightest shades of events and problems, without losing one's temper even at critical moments of the conflict.

Objectivity. It is the ability to approach a conflict situation from different perspectives. The behavior of the party to the conflict can be assessed in different ways depending on the position. It is important to be able to evaluate, compare, connect different positions. Objectivity means going beyond the problem situation. As a rule, all unsolvable situations are unsolvable only in some initially set framework of circumstances. If we understand them only as a part of global, world problems, then it helps to find a way out of an extreme situation. There are no hopeless situations. 
Foresight. This is the ability not only to understand the internal logic of the events of a conflict situation, but also to see the perspectives of their development. Knowing what this or that decision will lead to, protects against mistakes and wrong line of behavior, prevents the formation of a new and repeated conflict situation.

The expected results of the program are presented in Table 4.

Table 4. Expected results of the conflict management program in the educational environment.

\begin{tabular}{ll}
\hline Expected Results Category & Program Results \\
\hline $\begin{array}{l}\text { Benefits } \\
\text { for an educational institution }\end{array}$ & $\begin{array}{l}\text { Increases operational efficiency } \\
\text { Improves the image of the educational institution } \\
\text { Improves and develops a wide variety of management skills and communication } \\
\text { competencies }\end{array}$ \\
$\begin{array}{l}\text { Benefits } \\
\text { for line top managers (a head ofdisruption of the routine of activities (conflicts are resolved in the working order) } \\
\text { educational } \\
\text { institution and deputies) }\end{array}$ & $\begin{array}{l}\text { The program can be immediately applied and integrated } \\
\text { Focus on achieving effective performance }\end{array}$ \\
Benefits for teachers & $\begin{array}{l}\text { Focus on the most relevant aspects of the activity } \\
\text { Integrating skills into daily work } \\
\text { Orientation to individual psychological communication needs } \\
\text { Providing an opportunity to receive feedback in conflict communication and act on its } \\
\text { basis }\end{array}$ \\
\hline
\end{tabular}

In our opinion, the application of the communicative failure model and the proposed program will contribute to the optimization of conflict management in general education institutions.

For the adequate implementation of this model, it is necessary to develop the conflictological competency of the managers.

\section{DISCUSSION}

We propose the following model for transforming communicative failure into communicative conflict:

- Fixation of obvious non-harmonic interaction;

- Revealing the zone of communicative risk;

- Fixation of the speech act, which led to the communicative failure, its linguistic conflict potential;

- Analysis of the replies of the communicants after falling into a communicative failure in the direction of harmonization or disharmonization;

- Conditions for the transformation of communicative failure into a communicative conflict;

- Direction of speech actions in a situation of communicative conflict: harmonization or destruction of communication.

The proposed model of the communicative failure deployment allows us to analyze each non-harmonic communicative situation, identifying the causes of its occurrence, relying on verbal (non-verbal) communication.

Thus, the analysis of conflict could be reduced to the analysis of the communicative environment of general education institutions, in conjunction with the analysis of the conflict situation in the institution.

On the basis of this conclusion, a program for optimizing conflict management in general education institutions was developed, which could be adapted to any educational environment. 
The purpose of the program: to provide methodological tools for successful resolution of conflicts arising in professional activities in order to optimize the process of conflict management in general educational institutions.

Objectives of the program:

1) to develop an algorithm for conflict management, which provides for step-by-step actions of the conflict management subjects;

2) to define scenarios for resolving the conflict;

3) to formulate the attitudes of the subject of conflict management.

Target groups (depending on the type of conflict and its scale):

- managers of a general educational institution;

- immediate superiors of opponents;

- psychologist of an educational institution.

Program structure:

- scenarios for resolving the conflict;

- requirements for the subject of conflict management;

- expected outcomes of the program.

The structural components of the model for the conflictological competency development of the head of an educational institution are the goal, objectives, areas of activity for the formation of individual components of conflictological competency (content), institutional forms and methods, criteria for the development and levels of conflictological competency of the head of an educational institution. The functional components of a model include sustainable relationships between structural components and a way of organizing the work of the presented model.

The most significant tasks of the conflictological competency development of the head of an educational institution can be determined as follows:

- to gain the necessary and sufficient amount of theoretical knowledge in the field of conflict management in an educational institution and between participants in educational relations;

- to form the necessary amount of skills to determine and develop a strategy and tactics of one's own behavior in conflict situations, as well as in situations of pre-conflict interaction of participants in the educational process, requiring the intervention of the head of an educational institution;

- to form in the head of an educational institution the values of conflict-free interaction, personal motivation for the need to find effective ways to resolve conflict situations, focus on the implementation of a restorative approach in resolving conflict situations;

- to ensure the formation of a positive experience in resolving conflict situations in an educational institution by modeling educational environment.

The substantial component of the model for the development of conflictological competency is revealed through purposeful activity on the formation of its cognitive, operational and personal components. All components should be considered in interrelation, which confirms the complex structure of the studied phenomenon. The development of the components of conflictological competency affects the development of other competencies.

Also, the complexity of the phenomenon of conflictological competency of the head of an educational institution, and, consequently, its complexity, lies in the fact that this phenomenon is both part of the socio-psychological and part of professional competencies. Therefore, it is not enough to consider aspects of the conflictological competency of the head of an educational institution in relation only to the activities of an educational institution. It is also necessary to pay attention to a wider spectrum that ensures the development of conflictological competency in various aspects of social interaction.

The institutional and methodological block of the model for the development of conflictological competency of the head of an educational institution is represented by methods 
and forms of organizing activities aimed at the competency development.

The evaluative and productive block is represented by structural components, including the criteria of development and the levels of manifestation of conflictological competency. The grouping of the criteria was based on the effectiveness of the head of an educational institution in a particular area. Thus, we identified three criteria: the effectiveness of conflict resolution, conflict prevention and conflict management.

Analysis of the data according to the Thomas-Kilmann Conflict Mode instrument revealed the following: such a strategy of behavior as Compromising (50\%) in a conflict situation is chosen most often, i.e. these people somewhat lower their requirements, concede in their interests to others. As a result of the counter movement, each of the parties achieves a partial satisfaction of its desire and a partial fulfillment of the desire of the other party.

Next comes the Collaborating strategy, which scores $14 \%$. The Competing strategy gives a percentile score of $14 \%$. And also the Avoiding strategy scored $11 \%$. This mode is realized when a person does not defend his/her rights, does not cooperate with anyone to develop the best solution, evades, avoids resolving the conflict (Figure 1).

Figure 1. Results of the study of interpersonal conflict-handling modes.

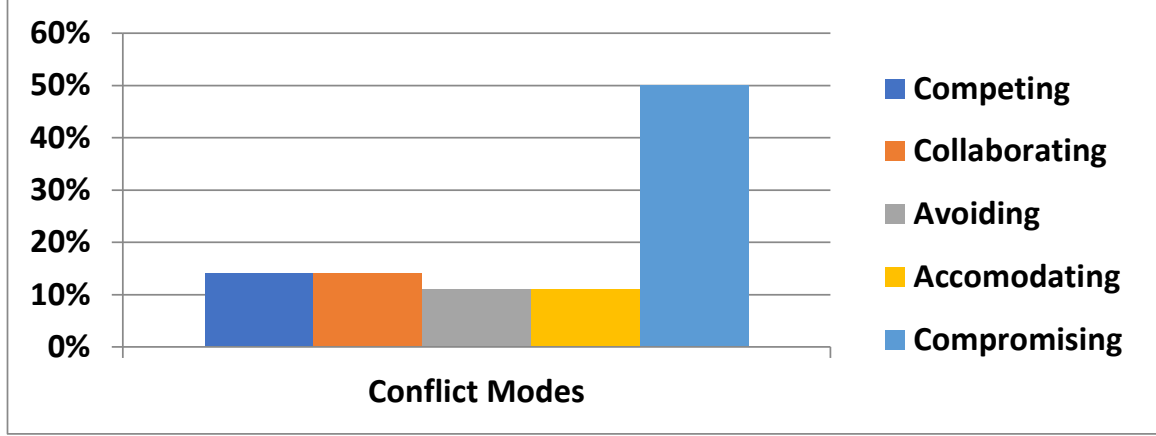

Based on the data obtained, we can conclude that the most often chosen strategy was Compromising, which indicates a high degree of collectivity, the desire to find a common ground and reach agreement, establish connections and improve relations.

\section{CONCLUSION}

By the effectiveness of conflict resolution by the head of an educational institution within the framework of the proposed model, we mean the level of satisfaction of the participants in the conflict interaction, achieved as a result of actions aimed at resolving the conflict on the part of the head. In other words, the higher the level of satisfaction of each of the parties to the conflict as a result of its resolution, the less losses (forces, time and other resources), the more effective the conflict resolution can be considered. Also, we associate the ratio of the number of conflicts resolved with a sufficient level of satisfaction of each of the parties to the total number of conflicts in, to the solution of which the head of an educational institution was involved.

The effectiveness of conflict prevention in an educational institution is proved by a decrease in the number of conflicts (primarily, open destructive confrontations) between participants in educational relations due to the implementation of a targeted system of measures on the part of the head of an educational institution (creating a favorable psychological climate, implementing the principles of humanity in the relationships of participants in educational relations, goodwill and trust, development and implementation of high-quality local regulations of the institution as regulators of relationships, etc.).

The criterion of the effectiveness of conflict management in an educational institution is revealed through the quality of the leader's activities aimed at timely diagnostics and assistance to 
the participants in conflicts (primarily latent ones) in changing their views on the subject of conflict, dissatisfaction in order to prevent the transition of the conflict into an acute phase with the involvement of a large number of participants.

Authors' Contributions: Sergeeva, M. G.: conception and design, acquisition of data, analysis and interpretation of data, drafting the article, critical review of important intellectual content. Lukashenko, D. V.: conception and design, acquisition of data, analysis and interpretation of data, drafting the article, critical review of important intellectual content. Kunitsyna, M. L.: conception and design, acquisition of data, analysis and interpretation of data, drafting the article, critical review of important intellectual content. Abdula-Zade, K. Z.: conception and design, acquisition of data, analysis and interpretation of data, drafting the article, critical review of important intellectual content. All authors have read and approved the final version of the manuscript.

Ethics Approval: Not applicable.

Acknowledgments: Not applicable.

\section{REFERENCES}

Astakhova, Yu. L. (2013). Conflict management methods in the teaching staff of the school. Concept, 3(19), 62-67.

Bírová, J., Kružlík, P., Kalimullin, A., Sokolova, N., Haroun, Z., Králik, R., \& Vasbieva, D. (2018). Mathematical and Statistical Bibliometric Indicators for Scholars in the Field of Romance Languages and Linguistics. EURASIA: Journal of Mathematics, Science and Technology Education, 14(12), em1638. https://doi.org/10.29333/ejmste/97826

Blinova, S., Dugina, T., \& Zabolotskikh, A. (2018). Teaching mixed nationality groups (on the example of students from the Northern Caucasus region). In: INTED2018: Proceedings of the 12th International Technology, Education and Development Conference, Valencia, Spain, pp. 7977-7982.

Coser, L. (2007). Fundamentals of conflict management. St. Petersburg: Publishing House Svetlyachok, 230 p.

Danilenko, S. V. (2014). Pedagogical conflict situations, technologies for their resolution. Young Scientist, 7, 500-502.

Dolzhich, E., \& Dmitrichenkova, S. (2018). Computer science terminology (a case study of the Spanish language). In: INTED2018: Proceedings of the 12th International Technology, Education and Development Conference, Valencia, Spain, pp. 2556-2559.

Gorev, P., Telegina, N., Karavanova, L., \& Feshina, S. (2018). Puzzles as a didactic tool for development of mathematical abilities of junior schoolchildren in basic and additional mathematical education. EURASIA: Journal of Mathematics, Science and Technology Education, 14(10), 178-185. https://doi.org/10.29333/ejmste/93675

Gulaeva, M. I. (2015). Conflict management in an educational institution. Innovative Science, 10, 95-97.

Magdeev, A. M., \& Mukhadinov, V. R. (2012). Prevention and resolution of pedagogical conflict: traditions and innovations. Integration of education, 4, 86-90.

Rybakova, M. M. (2012). Conflict and interaction in the pedagogical process. Moscow: Publishing House Education, 128 p.

Selivanova, E. A. (2012). The role of the teacher in the emergence and resolution of pedagogical conflicts. Scientific support of the personnel development system, 5, 34-39.

Sharonova, S., Trubnikova, N., \& Sokolova, N. (2018). Interpreting religious symbols as basic component of social value formation. European Journal of Science and Theology, 14(3), 117-129.

Sheverev, V. A., \& Kiseleva, E. V. (2018). Causes of interpersonal conflicts among adolescent athletes in a football team and pedagogical methods for their resolution. Sports and pedagogical education: a network publication, 2, 44-47.

Svetlov, V. A. (2003). Conflict management. New technologies of decision making in conflict situations. Moscow: Publishing House Rostok, 253 p.

Tekucheva, I. V., \& Gromova, L. Y. (2016). On present state of teaching Russian language in Russia. International Journal of Environmental and Science Education, 11(14), 6504-6511.

Uchadze, S. S. (2010). Pedagogical management of conflicts in an educational institution: monograph. Stavropol: Stavropol Book Publishing House, 287 p. 
Vasbieva, D. G., Sokolova, N. L., Masalimova, A. R., Shinkaruk, V. M., \& Kiva-Khamzina, Y. L. (2018). Exploring the EFL teacher's role in a smart learning environment - a review study. XLinguae, 11(2), $265-274$. http://dx.doi.org/10.18355/XL.2018.11.02.21

Volkova, Y., \& Panchenko, N. (2018). Discourse variation of the concepts of destructive emotions. Vestnik Rossiiskogo Universiteta Druzhby Narodov. Russian journal of linguistics, 22(1), 175-194.

https://doi.org/10.22363/2312-9182-2018-22-1-175-194

Received: 31 June 2021 | Accepted: 22 August 2021 | Published: 11 October 2021

This is an Open Access article distributed under the terms of the Creative Commons Attribution License, which permits unrestricted use, distribution, and reproduction in any medium, provided the original work is properly cited. 